九州大学学術情報リポジトリ

Kyushu University Institutional Repository

\title{
Ethanol Production by Encapsulated Rhizopus oryzae from Oil Palm Empty Fruit Bunch
}

Sahlan, Muhamad

Department of Chemical Engineering, Faculty of Engineering, University of Indonesia

Muryanto

Department of Chemical Engineering, Faculty of Engineering, University of Indonesia

Hermansyah, Heri

Department of Chemical Engineering, Faculty of Engineering, University of Indonesia

Wi jarnako, Anondho

Department of Chemical Engineering, Faculty of Engineering, University of Indonesia

他

https://doi.org/10.5109/2740963

出版情報 : Evergreen. 7 (1)，pp.92-96，2020-03. 九州大学グリーンテクノロジー研究教育センター バージョン：

権利関係 : 


\title{
Ethanol Production by Encapsulated Rhizopus oryzae from Oil Palm Empty Fruit Bunch
}

\author{
Muhamad Sahlan ${ }^{1,2, *}$, Muryanto ${ }^{1,3}$, Heri Hermansyah ${ }^{1}$, Anondho Wijarnako ${ }^{1}$, \\ Misri Gozan ${ }^{1,2}$, Kenny Lischer ${ }^{1}$, Ali Ahmudi ${ }^{4}$, Paksi Pujianto ${ }^{1}$ \\ ${ }^{1}$ Department of Chemical Engineering, Faculty of Engineering, University of Indonesia, Campus UI Depok, \\ 16424, West Java, Indonesia. \\ ${ }^{2}$ Research Center for Biomedical Engineering, Faculty of Engineering, University of Indonesia, Campus UI \\ Depok, 16424, West Java, Indonesia \\ ${ }^{3}$ Chemical Research Centre, Indonesian Institute of Science, Tangerang Selatan, Banten, 15314, Indonesia. \\ ${ }^{4}$ Center for Energy, Environment and Sustainable Development Studies, Faculty of Science and Technology, \\ Binawan University, Jakarta, 13630, Indonesia \\ *Corresponding author: Muhamad Sahlan \\ E-mail: sahlan@che.ui.ac.id
}

(Received November 1, 2019; Revised February 28, 2020; accepted March 10, 2020).

\begin{abstract}
Oil-palm empty fruit bunch (EFB) is abundant from palm-oil industries. One potential utilization of Rhizopus oryzae is the saccharification and fermentation process (SSF) for ethanol and lactic acid production. However, there some problems related to the optimum temperature and $\mathrm{pH}$ tolerance of $R$. oryzae. Encapsulating $R$. oryzae can help to improve the SSF process. The purpose of this research was to encapsulate the $R$. oryzae with a calcium alginate polymer to improve the tolerance of $R$. oryzae cells, which are required to convert EFB to bioethanol, in varying $\mathrm{pHs}$ and temperatures. The capsules were tested for their adaptability in high temperatures and varying midrange $\mathrm{pH}$. The resulting data from the experiment showed that the encapsulation of $R$. oryzae increased the production of bioethanol, from pretreated EFB through SSF, by $17 \%$ compared to that produced by $R$. oryzae free cells. The highest yield of ethanol from pretreated EFB was approximately $0.43 \mathrm{~g} / \mathrm{g}$ cellulose, with a maximum ethanol yield of $75.89 \%$, theoretically.
\end{abstract}

Keywords: cellulase, empty fruit bunch, encapsulation, lignocellulose, Rhizopus oryzae.

\section{Introduction}

The cellulosic fraction of lignocelluloses is biologically converted to ethanol via two processes: first, enzymatic saccharification converts cellulose to glucose monomers, and then, glucose fermentation by fungi converts glucose to ethanol. These two steps either occur separately in different chambers, in a process referred to as separate enzymatic hydrolysis and fermentation (SHF) processes, or simultaneously in a fermentor, via a process referred to as simultaneous saccharification and fermentation (SSF). The SSF process has some direct benefits. The fermentation of saccharides immediately after saccharification reduces fermentation retardation caused by monosaccharide or disaccharide accumulation 1,2,3). This increases the saccharification and fermentation rates, which improve productivity, thus reducing the reactor volume and capital costs ${ }^{4)}$. However, other factors, such as differences between saccharification and fermentation for the optimum $\mathrm{pH}$ and temperature, affect the efficiency of SSF ${ }^{5}$. The optimum temperature for saccharification is $40{ }^{\circ} \mathrm{C}-45^{\circ} \mathrm{C}$, whereas that for fermentation is $30^{\circ} \mathrm{C}^{4)}$. Furthermore, bare yeast is sometimes exposed to harsh external conditions during the industrial fermentation ${ }^{6}$.

Several attempts have been made to solve those problems. One of these is the cell encapsulation technique $6,7,8,9)$, which isolates the microorganisms and creates a barrier between them and their environment. Liquids, semi-liquids (gels) or solid films are often used to shroud individual cells or tissues to protect them and to achieve greater stability in the laboratory and industrial applications. Encapsulation uses polymers and biopolymers such as sodium alginate. The main reason for the use of polymer encapsulation is its ability to withstand different phases, such as liquid, gel, or solid, which enables it to have sufficient physical and mechanical strength ${ }^{7)}$. Encapsulated cells have been shown to increase the production of ethanol from dilute acid wood waste ${ }^{9)}$. This technique does not affect the metabolism and viability of the cell used 6). Additionally, in 
comparison with free cells, encapsulated R.oryzae have been shown to increase the production of lactic acid ${ }^{10)}$ and ethanol ${ }^{11)}$. Some researchers have successfully increased the ethanol production from rice straw to produce ethanol in anaerobic and aerobic conditions using $R$. oryzae, Mucor indicus and Saccharomyces cerevisiae ${ }^{12,13) .}$

$R$. oryzae has several advantages over other microorganisms; it is capable of producing ethanol from spent sulfite liquor, assimilates xylose and all major hexoses in the liquor, and is tolerant to inhibitors in acid hydrolysates-lignocellulose ${ }^{12)}$. In this study, we aimed to produce ethanol from oil palm empty fruit bunch (EFB) via SSF using $R$. oryzae. The goal of this research was to increase the temperature tolerance of $R$. oryzae cells by encapsulating them with calcium alginate polymer. These capsules were examined for their adaptive ability to high temperature and different mid-range $\mathrm{pH}$.

\section{Materials and Method}

\subsection{Preparation}

Oil palm EFB was acquired from a state-owned company PTPN VIII in Malimping, Banten province, Indonesia. The EFB was then reduced in size to $1-3 \mathrm{~mm}$ before autoclaving in $10 \% \mathrm{NaOH}$ solution under $150{ }^{\circ} \mathrm{C}$ and $4 \mathrm{~atm}$ for 30 minutes. To neutralize the alkaline solution, the EFB was then cleaned with tap water. This pretreated EFB was kept at room temperature until required for SSF.

$R$. oryzae, acquired from SITH-ITB, Indonesia, was incubated for $48 \mathrm{~h}$ on potato dextrose agar at $32{ }^{\circ} \mathrm{C}$, and preserved as a culture stock at $4{ }^{\circ} \mathrm{C}$. $R$. oryzae from the culture stock was mixed into $100 \mathrm{~mL}$ pre-sterilized medium of glucose $(10 \mathrm{~g} / \mathrm{L})$, yeast extract $(1.0 \mathrm{~g} / \mathrm{L})$, $\mathrm{KH}_{2} \mathrm{PO}_{4} \quad(0.1 \mathrm{~g} / \mathrm{L}), \quad \mathrm{MgSO}_{4} .7 \mathrm{H}_{2} \mathrm{O} \quad(0.1 \mathrm{~g} / \mathrm{L})$, and $\left(\mathrm{NH}_{4}\right)_{2} \mathrm{SO}_{4}(0.1 \mathrm{~g} / \mathrm{L})$, and then cultivated in incubation at $32{ }^{\circ} \mathrm{C}$ for $7 \mathrm{~d}$ on an orbital shaker at $150 \mathrm{rpm}$ to instigate sporulation. The medium was sterilized in a $250 \mathrm{~mL}$ Erlenmeyer flask by autoclaving at $121^{\circ} \mathrm{C}$ for $15 \mathrm{~min}$.

Commercial enzymes Ctec2 (Novozymes) were the single enzymatic complex used in this analysis. Its activity was measured as FPU. The enzyme displayed $70 \mathrm{FPU} / \mathrm{mL}$ of activity. One unit of activity is specified as the number of enzymes generating $1 \mu \mathrm{mol}$ of glucose per minute from filter paper ${ }^{14)}$.

\subsection{Encapsulation of $\boldsymbol{R}$. oryzae}

Spores were centrifuged and diluted after cultivation to achieve the optimal concentration of spores which was measured using a hemocytometer. $R$. oryzae spores were suspended in $1 \% \mathrm{CaCl}_{2}$ solution at a concentration of $1 \times$ $10^{8}$ cells $/ \mathrm{cm}^{3}$. This mixture was added drop-wise into a sterile solution of $0.5 \%$ sodium alginate, which was stirred using a magnetic stirrer to produce capsules with an average diameter of $2-3 \mathrm{~mm}$.

\subsection{SSF process}

Medium containing $2.5 \mathrm{~g} / \mathrm{L}$ yeast extract, $2.5 \mathrm{~g} / \mathrm{L}$ peptone, $1.0 \mathrm{~g} / \mathrm{L} \mathrm{KH}_{2} \mathrm{PO}_{4}, 0.25 \mathrm{~g} / \mathrm{L} \mathrm{MgSO}_{4} \cdot 7 \mathrm{H}_{2} \mathrm{O}, 150.0$ $\mathrm{g} / \mathrm{L}$ pretreated oil-palm EFB and $0.05 \mathrm{M}$ citrate buffer was used for the SSF process in $250 \mathrm{~mL}$ Erlenmeyer flasks. The $\mathrm{pH}$ of the medium was adjusted to $4.5,5.0$, and 5.5 by introducing $2 \mathrm{~N} \mathrm{NaOH}$ or $1 \mathrm{~N}$ acetic acid. After the sterilization of the media, encapsulated $R$. oryzae and the required enzyme were added aseptically to each flask. The protein loading was $20 \mathrm{FPU} / \mathrm{g}$ pre-treated EFB. Each flask had a final volume of $100 \mathrm{~mL}$. All experiments were carried out in triplicate. The SSF process was performed under anaerobic conditions. During the process, the flasks were covered with a plastic cup in anticipation of the gas emitted and to prevent air from entering the flask. At the outset of the fermentation, and during processing, pure nitrogen gas was purged into the media. The SSF process was performed at $37^{\circ} \mathrm{C}$ and $150 \mathrm{rpm}$ in a shaker incubator for $96 \mathrm{~h}$.

\subsection{Glucose and ethanol analysis}

The composition of the EFB was tested in conjunction with NREL Chemical Analysis and Testing Procedure ${ }^{15)}$. Samples were collected every $24 \mathrm{~h}$ from the SSF process and analyzed through high-performance liquid chromatography (Waters 2695, Milford, MA). An Aminex HPX-87H column (Bio-Rad, Richmond, CA, USA) and RI Detector (Waters, 2414) were used to analyze glucose and ethanol at $65{ }^{\circ} \mathrm{C}$ with $0.6 \mathrm{~mL} / \mathrm{min}$ eluent of $5 \mathrm{mM}$ sulphuric acid along $25 \mathrm{~min}$ retention time.

\subsection{Statistical analysis}

The resulting data was analyzed statistically using an alysis of variance to evaluate the effects of $\mathrm{pH}$ on ethanol production while using $R$. oryzae.

\section{Result and Discussion}

\subsection{Pretreatment of oil palm EFB}

The chemical composition of oil palm EFB in this study is listed in Table 1. Before the total pretreatment of carbohydrates in the oil palm, EFB was $48.86 \%$ and lignin fraction was $26.53 \%$ of dry biomass. The cellulose content after pretreatment increased from $33.64 \%$ to $60.34 \%$, whereas the lignin content decreased from untreated EFB to $47.14 \%$. The high cellulose content in pretreated EFB facilitates its conversion to bioethanol ${ }^{15}$.

Table 1. Chemical composition of untreated and pretreated oil palm empty fruit bunch (EFB)

\begin{tabular}{ccc}
\hline Composition & Untreated EFB (\%) & Pretreated EFB (\%) \\
\hline Lignin & 37.84 & 20.00 \\
Cellulose & 33.64 & 60.34 \\
Hemicellulose & 15.22 & 11.52 \\
Other & 13.30 & 8.14 \\
\hline
\end{tabular}




\subsection{Ethanol production via SSF}

The SSF of pretreated EFB was carried out under anaerobic conditions. Cellulose fraction in EFB was converted to glucose using cellulase enzymes, and $R$. oryzae simultaneously converted glucose to ethanol. At the beginning of SSF, the mixture contained $20 \mathrm{~g} / \mathrm{L}$ glucose, which was derived from glucose by the cellulase enzymes, and $\beta$-glucosidase was added to the SSF process (Fig. 1). Glucose concentration increased in the first $24 \mathrm{~h}$ and then decreased until the end of the SSF process, indicating the saccharification/hydrolysis of the long carbon chains of cellulose in pretreated EFB to glucose monomers by cellulase enzymes and $\beta$-glucosidase ${ }^{12}$. Enzymatic saccharification works specifically for cellulose to break down long chains of glucose monomers so that the resulting glucose production would be more optimal. Glucose concentration decreased to $1 \mathrm{~g} / \mathrm{L}$ by the end of the SSF process, i.e., at $96 \mathrm{~h}$, indicating that glucose was converted by $R$. oryzae during SSF process.

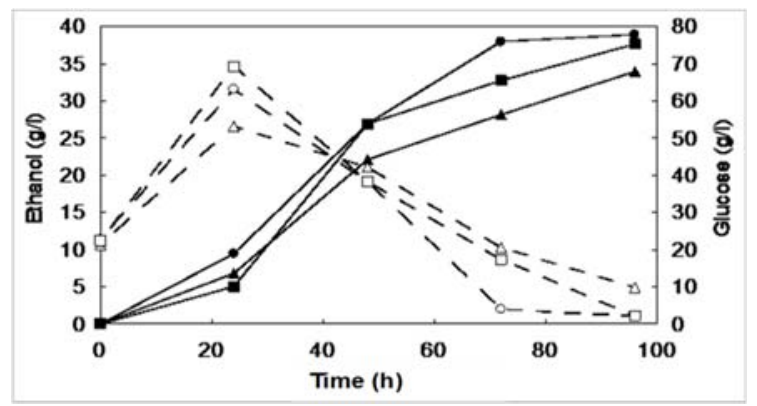

Fig. 1. Glucose and ethanol production using encapsulated $R$. oryzae at variable $\mathrm{pH}$. Empty symbols indicate the glucose concentration, and filled symbols indicate ethanol concentration. Triangles, circles, and squares represent $\mathrm{pH} 4.5$, 5.0 , and 5.5 , respectively.

Ethanol production began before $24 \mathrm{~h}$. In the first $24 \mathrm{~h}$, ethanol concentration was low possibly because $R$. oryzae cells were in the process of adapting to pretreated EFB media. After $24 \mathrm{~h}$, ethanol production increased and reached a maximum at $96 \mathrm{~h}$. Ethanol concentration at $\mathrm{pH}$ 4.5, 5.0, and 5.5 was $20.51,33.08$, and $26.78 \mathrm{~g} / \mathrm{L}$, respectively. The highest ethanol concentration was obtained at $\mathrm{pH} 5.0$, which is the optimum $\mathrm{pH}$ for saccharification $^{7,16)}$.

In the encapsulated cells, glucose is metabolized by $R$. oryzae present within the calcium alginate capsules. Glucose diffuses into the capsule through the calcium alginate walls, and ethanol produced from the fermentation process diffuses out through the capsule wall. Alginate concentrations are optimized to ensure proper diffusion of glucose and ethanol in or out of the capsule through the calcium alginate wall.

Encapsulation protects the $R$. oryzae cell from high ethanol concentration as well as the metabolites and toxic byproducts of saccharification and fermentation. The production of glucose and ethanol using encapsulation $R$. oryzae is shown in Fig. 1. The concentration of ethanol produced by encapsulated $R$. oryzae was $38.92 \mathrm{~g} / \mathrm{L}$ at $\mathrm{pH}$ $5.0,33.92 \mathrm{~g} / \mathrm{L}$ at $\mathrm{pH} 4.5$, and $37.66 \mathrm{~g} / \mathrm{L}$ at $\mathrm{pH}$ 5.5. Ethanol concentrations at various $\mathrm{pH}$ were significantly different $(\mathrm{P}<0.05)$. These results are higher than those using free $R$. oryzae cells during the SSF process ${ }^{17)}$.

\subsection{Effect of $\mathrm{pH}$ on ethanol production using \\ encapsulated $R$. oryzae}

The concentration of ethanol produced from pretreated EFB via the SSF process using encapsulated $R$. oryzae was higher than that using free $R$. oryzae cells of in our previous work (Fig. 2). The concentrations of ethanol produced by encapsulated $R$. oryzae at $\mathrm{pH} 4.5,5.0$, and 5.5 in a row were $33.92,38.92$, and $37.66 \mathrm{~g} / \mathrm{L}$. These concentrations were approximately $17 \%$ to $65 \%$ higher than those using free $R$. oryzae cells.

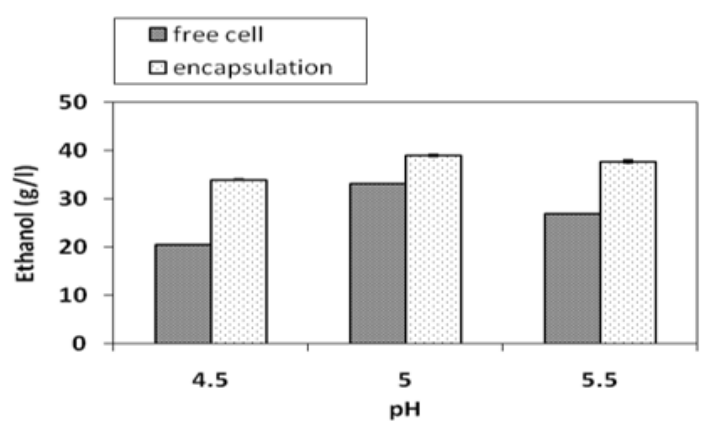

Fig 2. Comparison of ethanol production using free and encapsulated Rhizopus oryzae at variable $\mathrm{pH}$.

\subsection{Glucose and ethanol analysis}

$R$. oryzae is a filamentous fungus, which forms hyphae during growth. Although $R$. oryzae is known as the fungus of Tempe (Indonesian fermented food), the metabolism of $R$. oryzae through the glycolysis produces lactic acid and ethanol. $R$. oryzae converts glucose to pyruvic acid via the Embden-Meyers pathway. Glycolysis breaks down $1 \mathrm{~mol}$ of glucose to $2 \mathrm{~mol}$ of pyruvic acid via 10 enzymatic steps in the cell. Pyruvic acid is converted to three types of metabolites using different enzymes: fumarate by fumarase, lactic acid by lactate dehydrogenase (LDH) and pyruvate decarboxylase enzyme of ethanol with (PDC) and alcohol dehydrogenase (ADH). In anaerobic condition, $R$. oryzae tends to produce ethanol ${ }^{19)}$.

Cell encapsulation of $R$. oryzae proved to be effective in increasing the concentration of ethanol produced from pretreated EFB via the SSF process. Encapsulated cells are more resistant to adverse environmental conditions than free cells; in this study, adverse environmental conditions were represented by the $\mathrm{pH}$ during the SSF process. Encapsulation also protects the cells using artificial cell walls, which provide resistance to the cells against acidic conditions in solution. High $\mathrm{pH}$ induces 
stress on microorganisms, thus affecting their metabolism, whereas acidic $\mathrm{pH}$ slows down their metabolism run slower ${ }^{18)}$. Methods using free cells of $R$. oryzae are very susceptible to changes in $\mathrm{pH}$; a little change in $\mathrm{pH}$ lowers ethanol production, whereas encapsulated cells are more resistant to $\mathrm{pH}$ changes.

The results of this study approached those of Karimi et al. (2006) to get the max theoretical yield of about $60 \%$ of the rice straw substrate ${ }^{13)}$. Theoretically, the maximum glucose concentration generated by cellulase enzymes is $90 \mathrm{~g} / \mathrm{L}$, whereas the maximum ethanol content is $45 \mathrm{~g} / \mathrm{L}$. In this study, the maximum ethanol concentration was 33 $\mathrm{g} / \mathrm{L}$. It is good results if for fermentation using $R$. oryzae.

The production of ethanol from cellulose using encapsulated $R$. oryzae was higher than that using free cells; cell encapsulation increased ethanol production by $17 \%$ compared with free cells. Comparison of ethanol produced by research with theoretical reached $75.89 \%$ at $\mathrm{pH} 5.0$; the result is higher than the free cells as well as research by Karimi et al. ${ }^{13)}$. However, the encapsulation of cells is still slightly smaller than the result of cell encapsulation of $S$. cerevisiae by Ylitervo et al. (2011) ${ }^{9}$. It conducted fermentation with encapsulated $S$. cerevisiae in $30 \mathrm{~g} / \mathrm{L}$ glucose medium and produced ethanol (13.5 $\mathrm{g} / \mathrm{L}$ ) and the yield of $0.44 \mathrm{~g}$ ethanol $/ \mathrm{g}$ glucose.

The effect of $\mathrm{pH}$ of the medium on the production of ethanol was similar between encapsulated and free cells. Ethanol production was the highest ethanol production at $\mathrm{pH} 5.0$, regardless of the type of cells used. This suggests that $\mathrm{pH} 5.0$ is optimum for the SSF of pretreated EFB. At optimum $\mathrm{pH}, \mathrm{R}$. oryzae cells consume glucose at a faster rate, and the rate of ethanol production is higher.

The yield of ethanol using free and encapsulated $R$. oryzae is shown in Table 2.

Table 2. Concentration of ethanol produced from oil palm EFB via simultaneous SSF using $R$. oryzae cells encapsulated in calcium alginate polymer.

\begin{tabular}{ccccc}
\hline & $\begin{array}{c}\text { Maximum } \\
\text { ethanol } \\
\mathrm{pH}\end{array}$ & $\begin{array}{c}\text { Ethanol } \\
\text { yield } \\
\text { based on } \\
\text { cellulose } \\
(\mathrm{g} / \mathrm{g} / \mathrm{L})\end{array}$ & $\begin{array}{c}\text { Ethanol } \\
\text { yield } \\
\text { based on } \\
\text { pre-EFB } \\
(\mathrm{g} / \mathrm{g} \text { pre- } \\
\text { (efliulose })^{\mathrm{b}}\end{array}$ & $\begin{array}{c}\text { Maximum } \\
\text { theoretical } \\
\text { ethanol } \\
\text { yield }(\%)^{\mathrm{c}}\end{array}$ \\
\hline 4.5 & 33.9 & 0.4 & 0.2 & 66.1 \\
5.0 & 38.9 & 0.4 & 0.3 & 75.9 \\
5.5 & 37.7 & 0.4 & 0.3 & 73.4 \\
\hline
\end{tabular}

${ }^{\text {a }}$ Ethanol yield based on cellulose $=$ max ethanol/cellulose fraction in EFB (0.6034).

${ }^{\mathrm{b}}$ Ethanol yield based on EFB $=$ max ethanol/DM EFB $(150 \mathrm{~g} / \mathrm{L})$.

${ }^{\mathrm{c}}$ Maximum theoretical ethanol yield $=[\max$ ethanol $] /(0.51 \times 1.111 \times$ dry weight of $\mathrm{EFB} \times \mathrm{F}) \times 100, \mathrm{~F}=$ cellulose fraction in biomass $(0.6034)$.

The highest concentration of ethanol was produced after $96 \mathrm{~h}$, and the ethanol yield was based on cellulose content of pretreated EFB. Table 2 also compares the ethanol produced in this study with that produced according to a theoretical calculation. The results of the conversion of an existing substrate by free cells $R$. oryzae showed that the conversion is still quite small compared to the theoretical; mm cell $R$. oryzae only reached $65 \%$ at pH 5.0 and 4.0 and $52 \%$ at $\mathrm{pH} 4.5$ and 5.5.

The utilization of waste and side products of EFB production into bioethanol was the implementing sustainability in the industry, as it ensures the continuation of the fulfillment of human's basic needs ${ }^{20)}$. In Japan, various types of research have been performed using biomass to overcome the crisis of energy ${ }^{21)}$. EFB has the potential to be developed as bio-oil ${ }^{22)}$, production of xylose ${ }^{23)}$, the fiber as sustainable acoustic absorber ${ }^{24)}$, and hydrogen production ${ }^{25)}$.

\section{Conclusion}

Pretreated EFB is converted to ethanol via enzymatic hydrolysis followed by fermentation using $R$. oryzae. Encapsulation increases the resistance of the fungus against adverse conditions, such as $\mathrm{pH}$, chemical and temperature. This study investigates the influence of $R$. oryzae encapsulated in calcium alginate on ethanol produced. Ethanol concentration was the highest at $\mathrm{pH}$ of $5.0(38.92 \mathrm{~g} / \mathrm{L})$. Encapsulation of R. oryzae also increased its resistance to the temperature during fermentation, as the SSF process was carried out at $37^{\circ} \mathrm{C}$, which is higher than the commonly used temperature during fermentation $\left(32{ }^{\circ} \mathrm{C}\right)$. Additionally, the encapsulation of $R$. oryzae cells increased the production of ethanol by $17 \%$ compared with that produced by free cells of $R$. oryzae.

\section{Acknowledgments}

This research funded by DRPM Universitas Indonesia through PITT 9 Grant 2019 - Hibah Publikasi Internasional Terindeks untuk Tugas Akhir Mahasiswa (No. NKB-0067/UN2.R3.1/HKP.05.00/2019).

\section{References}

1) Ballesteros, M., Oliva, J. M., Negro, M. J., Manzanares, P., \& Ballesteros, I, Ethanol from lignocellulosic materials by a simultaneous saccharification and fermentation process (SFS) with Kluyveromyces marxianus CECT 10875, Process Biochem, 39(12), 1843-1848 (2004).

2) Bélafi-Bakó, K., Koutinas, A., Nemestóthy, N., Gubicza, L., Webb, C, Continuous enzymatic cellulose hydrolysis in a tubular membrane bioreactor, Enzyme Microb. Technol., 38(1-2), 155-161 (2006).

3) Sakimoto, K., Kanna, M., \& Matsumura, Y, Kinetic model of cellulose degradation using simultaneous saccharification and fermentation, Biomass and Bioenergy, 99, 116-121 (2017). 
4) Sun, Y., \& Cheng, J, Hydrolysis of lignocellulosic materials for ethanol production : a review, Bioresour. Technol., 83(1), 1-11 (2002).

5) Huang, L. P., Jin, B., Lant, P., \& Zhou, J, Simultaneous saccharification and fermentation of potato starch wastewater to lactic acid by Rhizopus oryzae and R. arrhizus, Biochem. Eng. J. 23(3), 265276 (2005).

6) Kampf, N, The use of polymers for coating of cells. Polym. Adv. Technol., 13(10-12), 895-904 (2002).

7) Talebnia, F., \& Taherzadeh, M. J, In situ detoxification and continuous cultivation of diluteacid hydrolyzate to ethanol by encapsulated $S$. cerevisiae, J. Biotechnol., 125(3), 377-384 (2006).

8) Ullah, M. W., Khattak, W. A., Ul-Islam, M., Khan, S., \& Park, J. K, Bio-ethanol production through simultaneous saccharification and fermentation using an encapsulated reconstituted cell-free enzyme system, Biochem. Eng. J., 91, 110-119 (2014).

9) Ylitervo, P., Franzén, C. J., \& Taherzadeh, M. J, Ethanol production at elevated temperatures using encapsulation of yeast, J. Biotechnol., 156(1), 22-29 (2011).

10) Haluk, H., \& Ryu, D. D. Y. Production of L ( + ) Lactic Acid Using Immobilized Rhizopus oryzae. Appl. Biochem. Biotechnol., 44, 125-133 (1994).

11) Millati, R., Niklasson, C., \& Taherzadeh, M. J, Effect of $\mathrm{pH}$, time and temperature of verliming on detoxification of dilute-acid hydrolyzates for fermentation by Saccharomyces cerevisiae, Process Biochem., 38, 515-522 (2002).

12) Abedinifar, S., Karimi, K., Khanahmadi, M., \& Taherzadeh, M. J, Ethanol production by Mucor indicus and Rhizopus oryzae from rice straw by separate hydrolysis and fermentation, Biomass Bioenergy, 33(5), 828-833 (2009).

13) Karimi, K., Emtiazi, G., \& Taherzadeh, M. J, Ethanol production from dilute-acid pretreated rice straw by simultaneous saccharification and fermentation with Mucor indicus, Rhizopus oryzae, and S. cerevisiae, Enzyme Microb. Technol., 40(1), 138-144 (2006).

14) Adney, B., \& Nrel, J. B, Measurement of cellulase activities: laboratory analytical procedure (LAP). National Renewable Energy Laboratory. Golden, Colo. (2008).

15) Kusrini, E., Supramono, D., Muhammad, I. A., Pranata, S., Wilson, D. L., \& Usman, A. Effect of Polypropylene Plastic Waste as Co-feeding for Production of Pyrolysis Oil from Palm Empty Fruit Bunches. Evergreen, 6(1), 92-97 (2019).

16) Ruiz, R., \& Ehrman, T, Chemical Analysis \& Testing Task, Determination of carbohydrate in Biomass by High-Performance Liquid Chromatography (Laboratory). Golden, Colo: Nat. Ren. Energy Lab. (1996).

17) Muryanto, Sahlan, M., \& Sudiyani, Y, Simultaneous Saccharification and Fermentation of Oil Palm
Empty Fruit Bunch for Bioethanol Production by Rhizopus oryzae, Int. J. Environ. Bioener. 3(32), 111120 (2012).

18) Sues, A., Millati, R., Edebo, L., Taherzadeh, M. J, Ethanol production from hexoses, pentoses, and dilute-acid hydrolyzate by Mucor indicus. FEMS Yeast Research, 5(6), 669-676 (2005).

19) Samsuri, M., Gozan, M., Hermansyah, H., Prasetya, B., Nasikin, M., \& Watanabe, T. Ethanol production from bagasse with combination of cellulasecellubiase in simultaneous saccharification and fermentation (SSF) using white rot fungi pre-treatment, J. Chem. Nat. Resources Eng, 3, 20-32 (2008).

20) Zahara, Z. F., Economic Assessment of the Sugarcane-based Bio-refinery in Indonesia, Evergreen, 5(2), 67-77 (2018).

21) Furutani, Y., Norinaga, K., Kudo, S., Hayashi, J. I., \& Watanabe, T. Current Situation and Future Scope of Biomass Gasification in Japan. Evergreen, 4(4), 2429 (2017).

22) Abdullah, N., \& Gerhauser, H. Bio-oil derived from empty fruit bunches. Fuel, 87(12), 2606-2613 (2008).

23) Rahman, S. H. A., Choudhury, J. P., \& Ahmad, A. L. Production of xylose from oil palm empty fruit bunch fiber using sulfuric acid. Biochemical Engineering Journal, 30(1), 97-103 (2006).

24) Or, K. H., Putra, A., \& Selamat, M. Z. Oil palm empty fruit bunch fibres as sustainable acoustic absorber. Applied Acoustics, 119, 9-16 (2017).

25) Sivasangar, S., Zainal, Z., Salmiaton, A., \& TaufiqYap, Y. H. Supercritical water gasification of empty fruit bunches from oil palm for hydrogen production. Fuel, 143, 563-569 (2015). 